\title{
Intervention and Display of Accounting Professional Judgment via Performance
}

\author{
Yufang Qi \\ Business School, Shandong Yingcai University, Ji'nan, 250101, China
}

\begin{abstract}
Keywords: Accounting professional judgment. Performance. Effect
\end{abstract}
\begin{abstract}
Accounting professional judgment runs through the whole process of accounting work and involves various aspects. It is a process where accounting personnel utilize their professional knowledge to judge and select daily accounting work in allusion to enterprise operation features in accordance with accounting standard and accounting system. Except reflecting current financial status of the enterprise, accounting professional judgment can also effectively maintain and promote economic benefit rise of the enterprise. This paper expounds the significance and effects of accounting professional judgment and the performance and proposes suggestions on the performance of current accounting professional judgment.
\end{abstract}

\section{Introduction}

Accounting personnel have very important status in the process of enterprise operation and development. One of their basic tasks is to provide high-quality accounting information. Accounting information can reveal economic activities of an enterprise from the accounting perspective. It is the foundation for an enterprise to make rational decisions and improve management. The performance of accounting professional judgment has direct influences on accounting information quality. So, to ensure accounting information quality, the researches on the performance of accounting professional judgment should be enhanced.

\section{Accounting professional judgment and the performance}

\section{Accounting professional judgment}

Accounting professional judgment refers to a process where accounting personnel utilize their professional knowledge to judge and select daily accounting work in allusion to enterprise operation features in accordance with accounting standard and accounting system. This process involves four aspects: the subject of judgment (i.e. professional accounting personnel); the object of judgment (i.e. economic affairs and preparation of related financial statements); judgment basis (i.e. real environment, laws and regulations, code of professional ethics and guiding ideas related to judgment); quality assurance (i.e. career experience, professional ability and supervision system).

Accounting professional judgment runs through the whole accounting process and involves many fields and links such as accounting recognition, measurement and recoding. It is an important means to judge whether economic business and accounting events are accounting elements, to confirm accounting elements and to decide the disclosure and the disclosure methods. Based on professional knowledge, accounting personnel should respect objective facts, remain neutral and truthfully reflect real effects of economic business on enterprise operation and development so as to guarantee accounting information quality. However, since the judgment itself decides the process will be influenced by many factors, accounting professional judgment has certain uncertainty and subjective element. Thus, accounting professional judgment is inevitably mingled with subjective judgment to some extent. Such subjective judgment is based on professional accounting knowledge of accounting personnel. In a sense, accounting professional judgment is technical and social dialectical unity. The technicality decides the judgment process, i.e. accounting professional judgment is the judgment of economic activities in the operation process by professional accounting personnel according to their professional knowledge and work experience. The whole judgment process reflects theoretical 
knowledge level and professional experience of the personnel. It is hard for non-professional personnel to make it. The sociality is decided by the following aspects: firstly, accounting professional judgment is restricted by social and economic environment, related laws and regulations, moral level and accounting work features. This leads to relative subjectivity of accounting professional judgment; secondly, the results of accounting professional judgment will impose important economic influences on interest decisions of credit investors, enterprise managers and relevant government departments.

High-quality accounting professional judgment can reflect practical situations of economic business and events of an enterprise, make enterprise managers and stakeholders gain real and valuable accounting information and promote rational allocation of social resources at a level. Low-quality accounting professional judgment cannot comprehensively and even correctly reflect actual situations of economic business and events of an enterprise. This will lead to damage to accounting information authenticity, increase the possibility of profit loss to enterprise managers and investors, mislead decision behaviors of enterprise managers and stakeholders and thus affect social resource allocation efficiency.

\section{Performance of accounting professional judgment}

In management science, performance is explained as the sum of descriptive work behaviors and measurable work results of individuals or groups in an organization in the special time. The performance of accounting professional judgment is concrete manifestation pattern of accounting professional judgment, intervenes and displays accounting professional judgment. It reflects the conformity degree of the result and standard of accounting professional judgment. The standard here includes two directions: effectiveness and efficiency. A good performance of accounting professional judgment should meet the two directions simultaneously. Theoretically, the judgment within or beyond accounting standard and accounting system must be based on authenticity and objectivity of accounting information. During accounting professional judgment, accounting personnel should consider the balance between objective neutrality and economic impact except professional skills. But, it is very difficult to accurately define the effectiveness and efficiency in the process of accounting professional judgment. This fundamentally leads to the difficulty in measuring accounting performance. According to previous research viewpoints and results, the influencing factors of the performance of accounting professional judgment are summarized as follows: accounting personnel factor, economic business and event factor, environmental factor and other accidental factors. Accounting personnel factor roughly contains professional knowledge of accounting personnel, accumulative experience, job motivation and effort level. Economic business and event factor refers to the subject of accounting personnel in accounting professional judgment, i.e. economic activities accounting personnel should judge. Environmental factor refers to the factor which cannot be changed through subjective intention during accounting professional judgment such as social and economic environment, related laws and regulations, accounting rules and systems, enterprise development objective and the intention of the management layer. Other accidental factors refer to those factors except personnel factor, economic business and event factor and environmental factor.

Finally, favorable performance of accounting professional judgment can not just make sure accounting work is conducted with high quality, but also should be the direction which is actively explored and pursued by accounting personnel and enterprise management. Moreover, the performance of accounting professional judgment also intervenes and displays accounting professional judgment. It is the foundation to evaluate the quality of accounting professional judgment, accounting work efficiency and determination of the responsibility of accounting personnel.

\section{Suggestion on boosting performance of accounting professional judgment}

In practical work, many factors will influence the performance of accounting professional judgment. As described above, these factors can be mainly classified into accounting personnel factor, 
economic business and event factor, environmental factor and other accidental factors. These factors will give rise to more or less influences on the performance of accounting professional judgment. If the influences of these factors are positive, the performance of accounting professional judgment will greatly improve. If negative effects occur, the quality of accounting professional judgment will reduce and the quality of accounting information will be then affected. Thus, the possibility of loss to enterprise decision-makers and stakeholders will increase. Therefore, rational suggestions must be put forward in allusion to these factors so as to avoid that the intervention and display effects of performance on accounting professional judgment cannot be effectively exerted.

\section{To perfect accounting regulation system}

Accounting Standards for Business Enterprises issued in 2006 have basically converge to international accounting standards for business enterprises. However, so far, the quality of Chinese accounting personnel is not high. Overemphasis of Accounting Standards for Business Enterprises may provide the loophole for making some false accounting information. If such circumstance occurs, it is inconsistent with the main requirements of accounting supervision and accounting information quality. Meanwhile, current provisions on preparation for the impairment of assets and confirmation of fair value lack systematicness. Besides, many problems need urgent solutions. Conceptual framework joint project of FASB and IASB originating in March 2003 can be referred to. FASB and IASB gradually clarify basic accounting concept. One of the most important joint projects is to review conceptual framework again. The objective is to establish a universal conceptual framework. The establishment of this conceptual framework has very important functions for guiding and evaluating accounting standard system. Meanwhile, it has long-term significance for internationally coordinating accounting standard. Current accounting regulation system applied in China should perfect calculation and withdrawal of impaired assets, switching assets back and confirming fair value. The absolute emphasis of the work is to govern abuse of accounting professional judgment of listed companies according to accounting regulations. On this basis, relevant supervision departments should formulate related rules. Accounting information authenticity can be guaranteed through reducing the difference of calculation and withdrawal policies. Accounting professional judgment standards and limiting conditions with reference and guidance can be prepared according to situations of different industries and asset impairment. Besides, detailed enforcement regulations can be prepared in accordance with current practical situations of accounting professional judgment. As well, the disclosure time, mode and condition for accounting professional judgment results can be standardized in detail to improve practicability and comparability of accounting information.

\section{To enhance scientific training plan}

The quality of accounting personnel is a main factor influencing the performance of accounting professional judgment. No matter how perfect the system is, the in-charge persons should abide by it. So, it can be said that the quality of accounting personnel is the most direct factor influencing the performance of accounting professional judgment. Thus, it is very important to boost the quality of accounting personnel. The quality of accounting personnel not only concludes professional knowledge and technical level, but also concludes experience accumulation, job motivation and effort level. On this basis, it is required to prepare scientific training plan to provide guarantee for improving the performance of accounting professional judgment. In terms of professional knowledge, to boost professional knowledge and accounting professional judgment ability of accounting personnel, business training and guidance for accounting personnel should be carried out regularly. The contents include explanation of new training norms, difficulties and key points of related laws and regulations and discussion of new economic business. In terms of professional ethics, training modes should be diversified, including special topic for policies and regulations, symposium, academic meeting, experience exchange, court simulation and case analysis, so as to promote accounting personnel to resist possible benefit lure, stick to principles, guarantee objectivity and fairness of accounting professional judgment results and provide guarantee for correct decision-making and development of the enterprise.

\section{To intensify duties of intermediary organs}


In order to boost the performance of accounting professional judgment, the duties of intermediary organs represented by certified public accountants should be intensified to make then really undertake and give play to the functions of auditing. Thus, accountants and other intermediary organs are required to stick to the principles of independence, objectivity and fairness to fully inspect the audit data. Once there is lack of objective data or there are large uncertainties, certified public accountants should decide whether to reveal such phenomenon in the audit report so as to ensure accounting information authenticity. Meanwhile, it is required to investigate and treat those certified public accountants and intermediary organs with jobbery.

\section{To perfect enterprise supervision structure}

Environmental factor influencing the performance of accounting professional judgment can mainly classified into internal factor and external factor of the enterprise. Firstly, for internal supervision system, it is required to gradually perfect enterprise governance structure and give full play to supervision right of board of directors and board of supervisors for economic business and events of the enterprise. Internal control system and especially internal accounting control system should be established gradually. It is required to pay special attention to loopholes and weak links of internal control system, continuously perfect and optimize internal environment of accounting professional judgment and then ensure authenticity and reference of accounting information. Secondly, for external supervision system, it is required to perfect social supervision system as early as possible, regard self-discipline as the core and give full play to constraint and supervision functions of certified public accountants for professional judgment. Furthermore, external supervision function of the government should be intensified. National supervision department strengthens constraints of accounting professional judgment behaviors legally so as to ensure objectivity and fairness of accounting information. Finally, relevant legal construction should be enhanced. Legislation should be perfected to formulate laws and regulations for accounting supervision. Besides, corresponding and specific punishment measures should be explicitly stipulated according to different situations of unlawful acts so as to supervise accounting personnel to keep awake all the time during accounting professional judgment and judge economic activities of the enterprise in accordance with laws, regulations, accounting standards and systems so as to improve the performance of accounting professional judgment.

\section{Conclusions}

Accounting professional judgment runs through the whole process of accounting work. Except reflecting current financial status of the enterprise, accounting professional judgment can also effectively maintain and promote economic benefit rise of the enterprise. The performance of accounting professional judgment can form good intervention and display functions for accounting professional judgment. The performance of accounting professional judgment will be bound to improve through adjusting the influencing factors of the performance of accounting professional judgment.

\section{References}

[1] Translated by Accounting Department of Ministry of Finance: Study on principle-based accounting system adopted in American financial reports, Beijing: China Financial and Economic Publishing House, 2003

[2] $\mathrm{Xu}$ Yude: On accounting professional judgment and accounting information quality, Public Finance Research, 2005(6)

[3] Xue Dawei, Han Zhimin, Luo Yan: Comprehensive evaluation of performance of accounting professional judgment, Journal of Heilongjiang Bayi Agricultural University, 2007(4)

[4] Zhang Zurong: Accounting information quality from perspective of accounting professional judgment, Journal of Pingyuan University, 2006(8) 
[5] Sun Dan: On accounting professional judgment [D]. Qingdao: Ocean University of China, 2005

[6] Wang Guoming: Analysis of factors influencing China's accounting professional judgment, Jiangsu Commercial Forum, 2004(6)

[7] Yang Sunlei, Li Yue'e: Evaluation of performance of accounting professional judgment with fuzzy comprehensive evaluation, Finance and Accounting Monthly, 2010(5)

[8] Xu Yude: Performance of accounting professional judgment, influencing factors and correction, Journal of Central University of Finance and Economics, 2006(11). 